\title{
VARIAN MAKNA KATA TOKI SEBAGAI NOMINA PENANDA KEWAKTUAN DALAM KALIMAT BAHASA JEPANG
}

\author{
Nani Sunarni \\ Fakultas Ilmu Budaya Universitas Padjadjaran \\ nani.sunarni@unpad.ac.id
}

\begin{abstract}
Abstrak
Penelitian ini difokuskan pada makna kata toki 'waktu' dalam kalimat bahasa Jepang. Data yang digunakan dalam penelitian ini berupa kalimat yang di dalamnya terdapat kata toki. Dari hasil analisis teridentifikasi tujuh makna kata toki, yaitu pertama kata toki yang memiliki makna denotative yaitu waktu. Dan yang lainnya yaitu digunakan untuk mengekspresikan waktu yang tepat dalam kondisi dilakukannya suatu kegiatan, kondisi atau kegiatan lain pun terjadi dalam waktu yang bersamaan, menyatakan waktu atau masa selama sesuatu berada dalam kondisi tertentu, dalam kondisi atau dalam situasi, menyatakan kesempatan, dan menunjukkan ekspresi yang bersifat kebiasaan. Selain itu, dalam kategori sebagai konjungsi toki yang dilekati oleh partikel ni (toki) digunakan dalam bahasa lisan untuk mengeksprresikan sesuatu yang tidak ada kaitannya dengan pembicaran sebelumnya.
\end{abstract}

Kata kunci: kesempatan, situasi, toki, waktu,

\begin{abstract}
This research is focused on the meaning of the word toki in Japanese sentences. The data used in this study is in the form of sentences in which there is the word toki. From the results of the analysis identified seven meanings of the word toki, namely the first toki word which has a denotative meaning namely time. And the other is used to express the right time in the condition of an activity, other conditions or activities occur at the same time, stating the time or time as long as something is in a certain condition, in a condition or situation, expressing an opportunity, and showing expression which is habitual. In addition, in the category of toki conjunctions clinging to ni (toki) particles are used in spoken language to express something that has nothing to do with previous speech.
\end{abstract}

Keywords: opportunity, situation, toki, time

\section{PENDAHULUAN}

Kanji toki (時) bila diurai terdiri atas dua kanji yaitu kanji nichi atau hi (日) yang bermakna matahari atau hari dan kanji tera (寺) yaitu kuil. Hubungan antara kedua kanji ini terkait erat dengan budaya dalam agama Budha yang dianut orang Cina dan orang Jepang. Para biksu yang tinggal di kuil mengumumkan waktu datangnya pagi, siang, dan malam dalam sehari ditandai dengan menabuh lonceng besar yang disebut kane (金). Hal ini, terdapat kesamaan dengan budaya masyarakat Indonesia yang pada umumnya sebagai pemeluk Islam. Sebagai penanda datangnya waktu sholat maka di masjid-masjid 
ditabuhlah bedug. Hanya dalam masyarakat Islam bedug ditabuh lima kali dalam sehari sebagai penanda waktu untuk menunaikan sholat lima waktu dalam sehari semalam. Kata toki (時) sudah muncul dalam buku yang berjudul Manyoushuu sebagai bahasa Jepang kuno (old japanese). Kata toki (時) dalam bahasa Indonesia sepadan dengan kata waktu atau masa. Menurut Kamus Besar Bahasa Indonesia kata waktu memiliki definisi (1) seluruh rangkaian saat ketika proses, perbuatan atau keadaan berada atau berlangsung; (2) lamanya; (3) saat yang tertentu untuk melakukan sesuatu; (4) kesempatan,tempo, peluang; (5) ketika; (6) hari; (7) saat yang ditentukan berdasarkan pembagian bola dunia (KBBI,1997: 1123).

Banyak makna kata yang menunjukkan waktu dalam bahasa Indonesia. Begitu pula dalam bahasa Jepang. Kata toki selain memiliki makna yang berbedabeda, juga memiliki beberapa kanji majemuk yaitu jikoku (時刻) seperti dalam frasa jikoku hyou (時刻表) 'jadwal atau schedule'、jikan (時間) seperti dalam dalam yomu jikan (読む時間) ‘waktu baca', dorian no jiki (ドリアンの時期) ‘musim durian' , do (度) dalam 2019 nendo ( 2019 年度) 'tahun fiscal 2019' dan lain-lain. Kata dalam bahasa Jepang selain terdapat kango (kata dalam bahasa Jepang yang menggunakan cara baca Cina) dan wago (kata dalam bahasa Jepang yang menggunakan cara baca Jepang atau kata yang berupa bahasa Jepang asli) terdapat pula gairaigo (kata serapan). Kata toki sepadan pula dengan kata gairaigo yaitu taimu タイム asal kata time 'waktu' seperti dalam kata kouhii taimu (コーヒ 一タイム) 'waktu minum kopi'. Kata toki (時) dibaca pula ji seperti dalam frasa sanji no oyatsu (3 時のおやつ). Kata ini tidak ada padanan dalam bahasa Indonesia, namun dalam bahasa Sunda disebut ngopi (makan makanan ringan di sore hari). Selain kata toki, kata penunjuk kewaktuan digunakan pula kata $u c h i$, tokoro. Selain itu, dalam bahasa Jepang kata yang menyatakan waktu tidak hanya berupa nomina seperti kedua kata di atas, namun dapat pula ditandai dengan kata atau morfem yang hanya memiliki makna gramatikal seperti Verba bentuk r ru dalam taberu tokoro 'saat akan makan', / te iru dalam tabete iru tokoro 'saat sedang makan', dan / ta dalam tabeta tokoro 'saat telah makan' dan lain-lain. Agar kajian ini terfokus, maka tujuan penelitian ini dibatasi pada penanda kewaktuan kata toki (時 yang dikaji secara struktur dan maknanya.

\section{METODE PENELITIAN}

Metode yang digunakan dalam penelitian ini adalah deskriptif kualitatif. Langkah-langkah penelitian dilakukan melalui beberapa tahap yaitu proses koleksi data, analisis data, dan penarikan simpulan. Sumber data penelitian ini diperoleh dari dua sumber. Sumber pertama adalah buku ajar berjudul Manabou Nihongo; Shochukyuu vol.3 tahun 2006. Penulis Igari Miho et.al. Tokyo: Senmon Kyouiku Shuppan. Sumber kedua untuk mendapatkan keabsahan data yaitu Gaikokujin no tame no Kihongo Yourei jiten, cetakan ke-2.tahun 1983. Penulis Asano Tsuruko et.al.Tokyo: Bunkachou. 


\section{HASIL DAN PEMBAHASAN}

Dari hasil analisis teridentifikasi bahwa terdapat tujuh jenis makna kata toki. Kata toki termasuk nomina abstrak (meishi). Secara makna kata ini dalam penggunaannya dapat dibedakan menjadi tujuh jenis, yaitu:

1. Menyatakan waktu atau jikan (時間)

Kata toki sebagai morfem bebas memiliki makna denotative atau makna konseptual atau dalam bahasa Jepang disebut gainenteki imi (概念的意味) yang sepadan dengan kata waktu dalam bahasa Indonesia, seperti dapat dilihat dalam contoh kalimat berikut.

a. Waktu

1) 朝、昼、晚と一日三度、時を知らせる鐘の音が聞こえる。 Asa.hiru.ban to ichi ni 3 do, toki o shiraseru kane no oto ga kikoeru. 'Pagi, siang, malam, terdengar bunyi genta yang memberitahukan waktu tiga kali dalam sehari'.

2) 時は金なり。

Toki wa kane nari.

'Waktu adalah uang'

Berdasarkan peribahasa Jepang di atas waktu (toki) disejajarkan pentingnya dengan uang (kane). Jadi maksudnya tidak boleh menyia-nyiakan waktu.'Peribahasa di atas sepadan dengan terjemahan bahasa Indonesia yaitu waktu adalah uang.

3）時を与えて、考えさせた方がいい。

Toki o ataete kangaesaseta hou ga ii.

'Sebaiknya (kita) biarkan dia berpikir dulu dengan memberinya waktu'

Verba ataete asal kata dari ataeru 'memberi' diubah kebentuk te karena merupakan kalimat majemuk menyambung dengan verba kangaesaseta. Kata atae (ru) dapat dihubungkan dengan kata toki 'waktu' sebagai objeknya. Dalam bahasa Jepang terdapat dua kata untuk mengungkapkan kata memberi yaitu ataeru dan ageru. Ataeru bermakna memberi sesuatu yang diharapkan lawan bicara. Sedangkan, ageru sepadan dengan kata memberi dalam bahasa Indonesia, seperti dalam contoh kalimat hon o ageru ' akan memberi buku'. Kalimat toki o ataete sama dengan shibaraku jikan o kakete.

4) 二、三日時をおいて（＝時が経ってから）たずねてみると、出来 上がっていました。

Ni,sannichi toki o oite, tazunete miru to dekiagatte imashita.

'Saat (saya) tanyakan selang dua, tiga hari, (ternyata) sudah selesai.'

5) 日本美術と西洋美術の展覧会が時を同じくして開かれている。 Nihon bijutsu to seiyou bijutsu no tenrankai ga toki o onajiku shite hirakarete iru. 
'Pameran kesenian Jepang dan kesenian Barat diselenggarakan dalam waktu bersamaan'.

Toki o shiraseru 'memberitahukan waktu' dalam kalimat (1), Toki o ataete 'memberi waktu' dalam kalimat (3), toki o oite 'setelah berlalunya waktu' dalam kalimat (4), dan dan toki o onajiku shite ' menyamakan waktu' dalam kalimat (5) berfungsi sebagai objek dalam kalimat tersebut. Sedangkan, Toki wa dalam kalimat (2) berfungsi sebagai subjek. Fungsi sintaksis dari masingmasing kalimat di atas dapat dilihat dalam table berikut.

Tabel 1: Fungsi Sintaksis dari kata toki dalam kalimat bahasa Jepang

\begin{tabular}{|c|c|c|c|}
\hline No & Kalimat & $\begin{array}{c}\text { Terjemahan dalam } \\
\text { bahasa Indonesia }\end{array}$ & Fungsi Sintaksis \\
\hline 1 & Toki o shiraseru & $\begin{array}{l}\text { memberitahukan } \\
\text { tentang waktu }\end{array}$ & \multirow{4}{*}{ Sebagai Objek } \\
\hline 2 & Toki o oite & $\begin{array}{l}\text { setelah berlalunya } \\
\text { waktu }\end{array}$ & \\
\hline 3 & Toki o ataete & memberi waktu & \\
\hline 4 & toki o onajiku shite & Menyamakan waktu & \\
\hline 5 & Toki wa & waktu adalah..... & Sebagai Subjek \\
\hline
\end{tabular}

Selain memiliki makna denotative toki 'waktu' yang berfungsi sebagai objek, toki hanya memiliki hubungan dengan verba-verba tertentu. Hubungan tersebut dalam bahasa Jepang disebut rengo (連語). Ogawa, 1962: 94 menjelaskan bahwa rengo to iu no wa futatsu ijou no go ga shitagainagara ketsugou shita mono de, mada bun to wa naranai mono (連語というのは二つ以 上の語が従いながら結合したもので、まだ文とはならないもの) ‘yang disebut rengo adalah dua atau lebih kata yang berkaitan dan saling melengkapi, namun belum menjadi kalimat. Berdasarkan definisi di atas, dalam bahasa Indonesia rengo sepadan dengan kolokasi. Kolokasi dalam kajian ini yaitu asosiasi hubungan makna kata yang satu dengan yang lain masing-masingnya memiliki hubungan ciri yang relatif tetap (Aminuddin, 2003:110). Kolokasi yang mengandung kata toki dapat dilihat dalam kalimat berikut.

6) あまり面白いので、時が経つのも忘れていました。 Amari omoshiroi node, toki ga tatsu no mo wasurete imashita.

'Karena begitu menariknya (saya) sampai lupa berlalunya waktu.'

7) この家に住んでもよいと言うと、彼は時をうつさずにもつを運んでき た。

Kono ie ni sunde mo yoi to iu to, kare wa toki o utsusazu nimotsu o hakonde kita. 
'Saat (saya) katakana bahwa (kamu) boleh tinggal di rumah ini, tanpa menunda waktu segera saja (dia) mengangkut barang-barangnya'.

8) 夕方までと、時を切って約束した。

Yuugata made to, toki o kitte yakusoku shita.

'(Saya) janji dengan membatasi waktu sampai sore hari'.

Verba tatsu ' berlalu' , utsusazu 'menunda', dan kitte 'membatasi' (berasal dari kata kiru 'memotong') berhubungan dengan kata toki seperti dalam kalimat ( 6), (7), dan (8) dan tidak dapat diganti dengan verba lain. Oleh karena itu, hal tersebut disebut kolokasi. Kolokasi toki o kitte sama hal nya dengan kalimat aru toki made kimete (ru) atau ditentukan pada waktu tertentu. Kolokasikolokasi tersebut dapat dilihat dalam table berikut.

Tabel 2: Rengo berunsur kata toki

\begin{tabular}{l|l|l}
\hline No & Kolokasi & Bahasa Indonesia \\
\hline 1 & Toki ga tatsu & Berlalunya waktu \\
\hline 2 & Toki o kitte & $\begin{array}{l}\text { Memutuskan sampai waktu } \\
\text { tertentu }\end{array}$ \\
\hline 3 & Toki o utsusazu & dengan Segera \\
\hline
\end{tabular}

2. Tepat dalam kondisi dilakukannya suatu kegiatan, kondisi atau kegiatan lain pun terjadi dalam waktu yang bersamaan.

Bahasa Jepang merupakan bahasa yang mengenal kala. Dalam bahasa Jepang istilah kala disebut jisei (時勢) atau tensu (テンス). Kala merupakan salah satu kategori semantik fungsional verba yang dinyatakan dengan perbedaan gramatika dengan melihat waktu pengerjaan kegiatan dan saat pengujaran dari kegiatan tersebut. Kala menunjukkan apakah kegiatan tersebut sudah, sedang, atau akan dilakukan. Dalam bahasa Jepang, kala dipandang dari terminologi waktu ujar. Secara garis besar kala terbagi dua yaitu kala lampau (kako-過去) dan nonlampau (hikako-非過去). Kala lampau ( kako) ditandai dengan sufik $\sim t a$ atau $\sim d a$ yang melekat pada verba seperti tabeta 'telah makan', nonda 'telah minum'. Sedangkan, kala nonlampau ditandai oleh verba bentuk $\sim r u$ atau word ending atau gobi $\sim \mathcal{u}$ untuk kala kini (genzai -現在) dan kala yang akan datang (mirai-未来) seperti kata taberu 'makan', nomu 'minum' . Serta bentuk te iru untuk menyatakan waktu sedang berlangsung. Seperti dapat dilihat dalam kalimat berikut.

9) うちを出る時には、晴れていました。

Uchi o deru toki ni wa, harete imashita.

'Pada waktu (akan) meninggalkan rumah (berangkat dari rumah),

(hari) cerah'

10) 夕飯を食べている時、電話がかかってきた。

Yuuhan o tabete iru toki, denwa ga kakatte kita.

'Pada saat sedang makan malam, ada telepon masuk'. 


\section{1) このとりは私がまどをあけた時に、飛び込んできたのです。}

Kono tori wa watashi ga mado o aketa toki ni, tobikonde kita no desu.

‘Burung ini melayang masuk ketika saya membuka jendela.

Toki dalam kalimat (9), (10), (11) melekat pada verba bentuk ru/ te iru/ ta toki (akan/sedang/telah. Berdasarkan ciri sintaksisnya, klausa pertama dari kalimat (9) menyatakan kegiatan akan berlangsung. Dan klausa keduanya menyatakan kondisi cuaca yang cerah pada waktu akan berlangsungnya aktifitas yang dinyatakan klausa pertama. Jadi, bila dirumuskan klausa pertama Verba( $\sim r u)$ toki dan klausa kedua Verba ( te) imashita. Kausa pertama dalam kalimat (10) menyatakan sedang berlangsungnya suatu kegiatan, dan dalam waktu yang bersamaan terjadi kejadian lainnya. Oleh karena itu, secara struktur klausa pertama berpredikat Verba( te) iru toki, dan klauasa kedua Verba te kita. Begitu pula klausa pertama dalam kalimat (10) terjadi setelah terjadinya kegiatan pertama, telah terjadi pula kejadian lain dalam waktu yang bersamaan.Bila dirumuskan kaliamat tersebut dalam klausa pertama berpredikat Verba ( ta) toki, dan klauasa ke dua Verba ( te) kita.Karena dalam klausa-klauasa dari kalimat majemuk (9), (10), (11) berdasarkan ciri-ciri semantisnya tidak menyatakan perbedaan tingkat pesan maka kalimat di atas digolongkan pada kalimat majemuk koordinatif.

3. Menyatakan waktu atau masa selama sesuatu berada dalam kondisi tertentu.

Waktu yang ditunjukkan dalam penggunaan ini dapat menunjukkan masa (jiki-時期), musim (kisetsu-季節), era atau zaman (jidai- 時代). Seperti dalam contoh berikut.

12) 若い時は二度とないのだから、何でもやってみることだ。

Wakai toki wa nido to nai no dakara, nande mo yatte miru koto da.

'Masa muda itu tidak akan datang lagi, jadi (kamu) harus mencoba melakukan berbagai macam hal'.

13) 子供の時は、何でもよく覚える。

Kodomo no toki wa, nande mo yoku oboeru.

'Semasa anak-anak (mah), segalanya ingat dengan baik'

14) 時が時だから(=ちょうど問題のある時だから。または、大切な時だ から。)身体に気をつけてください。

Toki wa toki dakara karada ni ki o tsukete kudasai.

'Karena sedang berada dalam masa-masa (pas di masa ketika ada permasalahan. Atau, di masa yang sangat penting) yang sangat penting, jadi jagalah kesehatan(mu).'

Selain klausa toki wa toki dakara terdapat sinonim dengan klausa toki mo toki dan ori mo ori (折も折) yang sepadan dengan dengan bahasa Indonesia tepat pada waktu itu atau dalam bahasa Jepang choudo sono toki 'tepat waktu itu' atau pas di masa ketika ada permasalahan atau di masa yang sangat 
penting. Ori bersinonim dengan kata kikai (機会) 'kesempatan', kisetsu (季 節)'musium', jiki (時季) 'masa' atau 'waktu'.

15) さくらの時にまたいらっしゃてください。 Sakura no toki ni mata irasshatte kudasai.

'Silakan datang lagi di musim sakura (bermekaran).'

16) 暑い時には、身体が疲れて、病気にかかりやすい。 Atsui toki ni wa, karada ga tsukarete, byouki ni kakariyasui.

'Pada waktu panas, tubuh cepat lelah, dan mudah terkena penyakit.'

17) 京都に都があった時は、この道もにぎやかだったそうだ。

Kyouto ni miyako ga atta toki wa, kono michi mo nigiyaka datta souda.

'Pada masa ibukota berada di Kyoto, jalan ini pun katanya ramai.'

18) 時の政府はこの問題を軽く考えていた。

Toki no seifu wa kono mondai o karuku kangaete ita.

'Pemerintah pada masa itu menganggap ringan masalah ini.'

Frasa wakai toki 'masa muda' dalam kalimat (12), kodomo no toki 'masa kanakkanak'dalam (13) miyako ga atta toki 'zaman beradanya ibu kota'dalam kalimat (17) menunjukkan masa atau zaman (jidai- 時代). Hal ini sesuai dengan pendapat Shinmura $(1991,1137)$ yang menyebutkan bahwa jidai- 時 代 adalah kugirareta, hitomatomari no nagai jikan 'waktu yang lama, dibatasi dan ditentukan. Hal ini sesuai dengan teori perkembangan manusia masa muda atau masa kanak-kanak ditentukan dan dibatasi oleh perubahan perkembangan fisik, perkembangan kognitif, perkembangan emosi, dan perkembangan psikososial (Jahja, 2011: 183-191). Begitu pula, keberadaan suatu ibukota ditentukan dan dibatasi oleh keberadaan tempat tersebut dan segala yang menguasainya,Oleh karena itu, toki tersebut merujuk pada zaman atau jidai sesuai dengan definisi di atas. Toki wa toki dakara dalam kalimat (14) dan atsui toki dalam kalimat (16) Toki no dalam (18) menunjukkan makna masa (jiki-時期). Hal ini, untguk kalimat (14) karena manusia dalam kehidupannya terkurung waktu, adakalanya sibuk, penting dan lain-lain. Selain itu, untuk kalimat (18) karena pada kenyatannya cuaca adakalanya panas, ada pula dingin. Oleh karena itu, disebut jiki. Dan kata toki no bermakna tepat pada waktu itu atau sono touji no (その当時の).

Table 3: Toki yang bermakna Menyatakan waktu atau masa selama sesuatu berada dalam kondisi tertentu.

\begin{tabular}{c|c|l}
\hline \multicolumn{1}{c|}{$\begin{array}{c}\text { Bentuk } \\
\text { Lingual }\end{array}$} & \multicolumn{1}{c|}{ Makna } & \multicolumn{1}{c}{ Keterangan } \\
\hline 若い時 & zaman (jidai- 時代). & $\begin{array}{l}\text { Waktu yang lama, dibatasi dan } \\
\text { ditentukan oleh perubahan } \\
\text { fisik, kognitif, emosi, } \\
\text { psikososial. }\end{array}$ \\
\hline 子供の時 & zaman (jidai- 時代). \\
\hline
\end{tabular}


Varian Makna Kata Toki sebagai Nomina Penanda Kewaktuan ...

\begin{tabular}{l|l|l}
\hline $\begin{array}{l}\text { 都があった時 } \\
\text { は }\end{array}$ & zaman (jidai- 時代). & $\begin{array}{l}\text { Waktu yang lama, dibatasi dan } \\
\text { ditentukan oleh perubahan } \\
\text { regulasi kekuasaan. }\end{array}$ \\
\cline { 1 - 2 } 時が時だから & masa (jiki-時期) & Ditentukan dibatasi oleh \\
\cline { 1 - 2 } 暑い時 & masa (jiki-時期) & Kondisi dan situasi. \\
\cline { 1 - 2 } 時の Toki no & masa (jiki-時期) & $\begin{array}{l}\text { Ditentukan dibatasi oleh } \\
\text { pergantian musim. }\end{array}$ \\
\cline { 1 - 2 } さくらの時 & (kisetsu-季節) & \\
\hline
\end{tabular}

4. Dalam kondisi atau dalam situasi

Makna toki selain memiliki makna waktu, dapat pula bermakna dalam kondisi atau dalam situasi waktu yang dalam bahasa Jepang sepadan dengan kata baai. Penggunaan tersebut dapat dilihat dalam kalimat berikut.

19) ちょうどいい時に来てくれましたね。早速てつだってください。 Choudo ii toki ni kite kuremashita ne.

'Tepat pada waktunya anda datang ya. Segera saja bantu saya.'

20) 困る時には互いに助け合うのは当たり前のことです。 Komaru toki ni wa tagai ni tasukeau no wa atari mae no koto desu. 'Pada saat kesusahan, sudah selayaknyalah kita saking menolong.'

21) いざという時（=急に大変なことが起こったとき）のために用意してお く金だ。

Iza to iu toki no tame ni youi shite oku kane da.

'Uang yang kusiapkan untuk saat-saat (pada saat sesuatu yang genting tiba-tiba terjadi) diperlukan.'

22）危険な時には、赤いランプがつきます。

Kikenna toki ni wa, akai ranpu ga tsukimasu.

'Pada saat bahaya, lampu merah akan menyala.'

23) ご用の時には、ベルを押して下さい。 Goyou no toki wa, beru o oshite kudasai.

'Pada waktu ada perlu, silakan pijit tombol bel.'

24) 今は喧嘩している時じやない。早く相談をまとめよう。 Ima kenka shite iru toki janai. Hayaku soudan o matomeyou.

'Sekarang bukan waktunya untuk berdebat. Ayo kita cepat simpulkan hasil pembicaraannya.'

25) 丁寧な言葉が、いいといっても時と場合によります。 Teineina koto kotoba ga, ii to itte mo toki to baai ni yorimsu. Meski bahwa bahasa halus itu bagus (digunakan), namun itu pun tergantung pada situasi dan kondisi. 
26）時と場所をよく考えて物事をしなければならない。 Toki to basho o yoku kangaete monogoto o shinakereba naranai.

'(Kita) harus melakukan sesuatu dengan mempertimbangkan baikbaik waktu dan tempat.'

27) 新聞社は、時に応じて（=場合によって）飛行機を飛ばすこともある。 Shinbunsha wa, toki ni oujite hikouki o tobasu koto mo aru.

'Perusahaan Surat Kabar, kadang-kadang menerbangkan pesawat tergantung situasi dan kondisi'

Secara struktur frasa choudo ii toki dalam kalimat (19), Komaru toki dalam kalimat (20), Iza to iu toki dalam kalimat (21), Kikenna toki dalam kalimat (22), Goyou no toki dalam kalimat (23), kenka shite iru toki dalam kalimat (24), ii to itte mo toki dalam kalimat (25), toki ni oujite toki dalam kalimat (27) dan toki to basho o yoku kangaete kalimat(26) menunjukkan situasi atau kondisi yaitu tepat pada waktunya, pada saat kesusahan, saat sesuatu yang penting tibatiba terjadi, waktu berdebat, waktu yang tepat untuk diungkapkan.

5. Kesempatan, kans.

Kata toki yang digunakan dalam kalimat majemuk seperti di bawah menunjukkan waktu yang tepat untuk melakukan sesuatu. Makna tersebut dapat dilihat dalam kalimat berikut.

28) 逃げる時は今だ。

Nigeru toki wa ima da.

'Untuk melarikan diri, sekaranglah saatnya (kesempatannya).'

29) 今度時があったら話しておきましょう。

Kondo toki ga attara hanashite okimashou.

'Nanti jika ada kesempatan akan saya utarakan.'

30) 自分のカを表す時を待っていたが、いよいよその時が来た。 Jibun no chikara o arawasu toki o matte ita ga, iyoiyo sono toki ga kita. 'Saya menunggu-nunggu waktu untuk menunjukkan kemampuan saya, dan akhirnya kesempatan itu tiba'

31）時を見て（=適当な場合を選んで）話しておきましょう。 Toki o mite hanashite okimashou.

'Saya akan melihat dulu saat yang tepat, nanti saya utarakan'

32) あの人は、立派な方なのに、時を得ないで（＝自分のカを充分に表す 機会がなくて）世に認められなかった。

Ano hito wa rippana kata nanoni, toki o enai de yo ni mitomerarenakatta.

'Padahal beliau itu orang yang hebat, namun karena tidak mendapatkan kesempatan (tidak mendapat kesempatan untuk menunjukkan kemampuannya secara maksimal), beliau tidak mendapat pengakuan dari masyarakat.' 
Varian Makna Kata Toki sebagai Nomina Penanda Kewaktuan ...

Tabel 4 : Hubungan semantik antarklausa Kalimat Majemuk setara

\begin{tabular}{|c|c|c|c|}
\hline $\begin{array}{c}\text { No. } \\
\text { Kalimat }\end{array}$ & Klausa pertama & Klausa kedua & $\begin{array}{c}\text { Hubungan semantik } \\
\text { antarklausa Kalimat } \\
\text { Majemuk setara. }\end{array}$ \\
\hline 28 & Nigeru toki wa & Ima da & $\begin{array}{l}\text { Topik dalam kalimat } \\
\text { tunggal. }\end{array}$ \\
\hline 29 & Kondo toki ga attara & hanashite okimashou & $\begin{array}{l}\text { Penjumlahan yang } \\
\text { menyatakan urutan } \\
\text { waktu. }\end{array}$ \\
\hline 30 & $\begin{array}{l}\text { Jibun no chikara o } \\
\text { arawasu toki o matte } \\
\text { ita ga }\end{array}$ & $\begin{array}{l}\text { iyoiyo sono toki ga } \\
\text { kita }\end{array}$ & $\begin{array}{l}\text { Penjumlahan yang } \\
\text { menyatakan urutan } \\
\text { waktu. }\end{array}$ \\
\hline 31 & Toki o mite & hanashite okimashou & $\begin{array}{l}\text { Penjumlahan yang } \\
\text { menyatakan urutan } \\
\text { waktu. }\end{array}$ \\
\hline 32 & $\begin{array}{l}\text { Ano hito wa rippana } \\
\text { kata }\end{array}$ & $\begin{array}{l}\text { toki o enai de yo ni } \\
\text { mitomerarenakatta }\end{array}$ & $\begin{array}{l}\text { Hubungan } \\
\text { perlawanan. }\end{array}$ \\
\hline
\end{tabular}

6. Menunjukkan Ekspresi yang bersifat kebiasaan.

Kata toki menunjukkan ekspresi yang bersifat kebiasaan. Kalimat yang bermakna tersebut merupakan kalimat majemuk yang bersifat berlawanan. Kalimat majemuk berlawanan atau bertentangan dalam bahasa Jepang diantaranya ditandai oleh partikel $g a$ 'tetapi', atau sebab akibat yang ditandai oleh partikel kara 'karena', seperti kalimat berikut.

33) いつも洋服ですが、時には着物を着るころもあります。 Itsumo youfuku desu ga, toki ni ha kimono o kiru koto mo arimasu.

'Biasanya selalu memakai pakaian ala barat, namun kadang-kadang memakai kimono juga'

34) ちょっとした不注意から、時として大きな事故を起こすことがある。 Chotto shita futsui kara, toki toshite ookina jiko o okosu koto ga aru.

'Akibat kelalaian kecil, (pada suatu saat tertentu) kadang-kadang timbul kecelakaan yang besar'

Kata toki dapat pula digunakan untuk mengekspresikan kalimat yang menunjukkan kebiasaan, namun dalam satu waktu terjadi sesautu yang tidak biasa dari keseharian atau kebiasaan tersebut. Kebiasaan dalam kalimat (33) ditandai dengan kata itsumo 'selalu'dan dalam kalimat (34) ditandai oleh makna semantic dari kedua klausa yang bersifat kontradiktif. Kekontrasan dalam kalimat (33) ditandai oleh penanda lingual yaitu yofuku yang berantonim dengan kimono dan dalam kalimat (34) ditandai oleh adanya kata shotto shita 'kecil' yang berantonim dengan ooki 'besar'. 
7. Toki ni

Kata toki selain sebagai meishi (nomina), juga berkategori setsuzokushi (konjungsi) yang diikuti oleh partikel ni (toki ni). Penggunaannya muncul di tengah-tengah percakapan. Konjungsi ini digunakan pada saat memunculkan topik yang tidak berkaitan dengan topik sebelumnya. Dalam bahasa Indonesia konjungsi ini sepadan dengan kata "ngomong-ngomong". Seperti dapat dilihat dalam contoh berikut.

35) 時に、お兄さんは今どうしていらっしやいますか。 Toki ni, oniisan wa ima doushite irasshaimasu ka.

'Ngomong-ngomong, bagaimana keadaan kakak anda sekarang?'

36) 時に、あの問題はどうなりましたか。

Toki ni, ano mondai wa dou narimashita ka.

'Ngomong-ngomong, bagaimana kelanjutannya masalah itu?'

\section{PENUTUP}

Kata toki yang berkategori nomina yang sepadan dengan kata waktu dalam bahasa Indonesia, dalam bahasa Jepang memiliki makna dan penggunaan yang bervariasi tergantung pada struktur kalimat yang mengandung kata toki tersebut. Kata toki tersebut digunakan pula untuk mengekspresikan kondisi atau dalam situasi dilakukannya suatu kegiatan, kondisi, menyatakan kesempatan, dan menunjukkan ekspresi yang bersifat kebiasaan. Selain itu, dalam kategori sebagai konjungsi toki yang dilekati oleh partikel ni (toki) digunakan dalam bahasa lisan untuk mengeksprresikan sesuatu yang tidak ada kaitannya dengan pembicaran sebelumnya. Dengan adanya berbagai makna dari kata toki dan sangat berbeda dengan kata waktu dalam bahasa Indonesia, oleh karena itu perlu diperhatikan terutama oleh pembelajar bahasa Jepang yang berbahasa ibu bahasa Indonesia.

\section{DAFTAR PUSTAKA}

Asano, Tsuruko. 1983. Gaikokujin no Tame no Kihongo Yourei Jiten. Tokyo: Bunkachou.

Aminuddin, 2003. Semantik. Malang: Sinar Baru Algensindo.

Alwi, Hasan. 2000.Tata Bahasa Baku Bahasa Indonesia. Jakarta: Balai Pustaka.

Akimoto, Miharu. 2002. Yoku Wakaru Goi. Tokyo: Aruku.

Iori, Isao et.al. (2000). Nihongo Bunpou Handobukku. Tokyo: Suriiee Nettowaaku.

Koizumi, Tamotsu.1993. Gengogaku NYuumon. Tokyo: Taishuukan Shoten.

Jahya, Yudrik. 2011. Psikologi Perkembangan. Jakarta: Kencana.

Shinmura, Izuru. 1991. Koujien ( Daiyonpan). Tokyo: Iwanami Shoten.

Sunagawa, Yuriko et.al. 1998.Nihongo Bunkei Jiten. Tokyo: Kuroshio Shuppan.

Tanaka, Harumi et.al. 1982. Gengogaku Enshuu. Tokyo: Taishuukan Shoten. 
Varian Makna Kata Toki sebagai Nomina Penanda Kewaktuan ... . 1097.Gendai Gengogaku Jiten. Tokyo: Seibidou.

Paina, Partana.2003.Semantik terjemah Leech, Geoffrey. Yogyakarta: Pustaka Pelajar Offset.

Y.Ogawa. 1992. Nihongo Kyouiku Jiten. Tokyo: Taishuukan Shoten. 